\title{
Modification of aluminium alkoxides with dialkylmalonates
}

\author{
Robert Lichtenberger • Stefan O. Baumann • \\ Maria Bendova $\cdot$ Michael Puchberger · \\ Ulrich Schubert
}

Received: 18 November 2009/ Accepted: 2 May 2010/Published online: 29 May 2010

(c) The Author(s) 2010. This article is published with open access at Springerlink.com

\begin{abstract}
Depending on the reaction conditions, different aluminium dialkylmalonate derivatives were obtained by reaction of aluminium alkoxides $\mathrm{Al}(\mathrm{OR})_{3}(\mathrm{R}=\mathrm{Et}, i \mathrm{Pr}, t \mathrm{Bu})$ with dialkylmalonates, viz. $\mathrm{Al}(\text { malonate })_{3} \quad$ (malonate $=$ dimethyl, diethyl, di-iso-propyl and di-tert-butyl malonate), $\mathrm{Al}_{2}(\mathrm{O} i \mathrm{Pr})_{4}(\text { malonate })_{2}$ (malonate $=$ di-iso-propyl and ditert-butyl malonate), $\mathrm{Al}_{2}(\mathrm{O} i \mathrm{Pr})_{2}$ (di-iso-propylmalonate $)_{4}$ and $\mathrm{Al}_{3}(\mathrm{OH})(\mathrm{OEt})_{3}(\text { diethylmalonate })_{5}$. All compounds were characterized by NMR spectroscopy, and single crystal structure analyses are reported for each type of compound. An $\mathrm{Al}_{2}(\mathrm{OiPr})_{2}$ (dialkylmalonate $)_{4}$ derivative was only obtained by disproportionation of $\mathrm{Al}_{2}(\mathrm{O} i \mathrm{Pr})_{4}(\text { di-iso-propylmalonate })_{2}$, but not by reaction of $\mathrm{Al}(\mathrm{O} i \mathrm{Pr})_{3}$ with dialkylmalonates in the corresponding molar ratio. Reactions of $\mathrm{Al}(\mathrm{O} t \mathrm{Bu})_{3}$ only resulted in $\mathrm{Al}(\text { malonate })_{3}$ derivatives, but no transesterification was observed, contrary to the reaction of $\mathrm{Al}(\mathrm{O} i \mathrm{Pr})_{3}$ with dimethyl or diethyl malonate.
\end{abstract}

Keywords Aluminium alkoxides - Dialkylmalonates · ${ }^{27} \mathrm{Al}$ NMR spectroscopy

\section{Introduction}

Substitution of one or more alkoxo groups of metal alkoxides by bi- or multidentate ligands is a well known and frequently used method to lower the reactivity of the metal alkoxides upon hydrolysis and to avoid formation of

R. Lichtenberger · S. O. Baumann · M. Bendova ·

M. Puchberger · U. Schubert ( $\square)$

Institute of Materials Chemistry,

Vienna University of Technology,

Vienna, Austria

e-mail: uschuber@mail.zserv.tuwien.ac.at precipitates instead of gels during sol-gel processing [1]. This is achieved by reducing the number of hydrolysable alkoxo groups, blocking of coordination sites at the metal centre and lowering the Lewis acidity of the metal centre [2].

A consequence of the Lewis acidity of the metal centres is the strong tendency of metal alkoxides to form alkoxobridged oligomers to attain higher coordination numbers. The degree of oligomerization is inversely correlated to the steric demand of the alkoxo group. Taking aluminium alkoxides as an example, dimeric $\left[\mathrm{Al}(\mathrm{O} t \mathrm{Bu})_{3}\right]_{2}$ is formed with tert-butoxo groups, tetrameric $\left[\mathrm{Al}(\mathrm{O} i \mathrm{Pr})_{3}\right]_{4}$ with isopropoxo groups, and even larger oligomeric, linear species $\left[\mathrm{Al}(\mathrm{OEt})_{3}\right]_{n}$ with ethoxo groups [3-7]. This tendency to form oligomers is retained after modification with organic ligands. For example, $\mathrm{Al}$ alkoxides and siloxides are known to form mono-, di-, tri- or oligomeric species after modification with $\beta$-diketones [8-10].

Various ligand classes have been used for the modification of metal alkoxides, e.g. $\beta$-diketonates, $\beta$-ketoesterates, amines, aminoalcoholates or oximates [11]. A systematic study on reactions of $\mathrm{Al}(\mathrm{O} i \mathrm{Pr})_{3}$ with $\beta$-ketoesters recently showed a dependence of the formed species on the reaction temperature. Formation of trisubstituted $\mathrm{Al}(\beta \text {-ketoesterate })_{3}$ is favoured at room temperature, independent of the applied stoichiometric ratio. To obtain monosubstituted $\mathrm{Al}_{2}(\mathrm{O} i \mathrm{Pr})_{4}$ $(\beta \text {-ketoesterate })_{2}$ (i.e. $\mathrm{Al} /$ ketoesterate ratio $\left.=1\right)$ higher reaction temperatures had to be applied or alternatively $\mathrm{Al}(\mathrm{O} i \mathrm{Pr})_{3}$ had to be thermally de-oligomerized prior to the reaction. No influence of the $\beta$-ketoester OR groups was observed, except for the reaction with tert-butyl acetoacetate, where transesterification was observed [12]. Based on these results, we investigated the modification of aluminium alkoxides with dialkylmalonates. To the best of our knowledge, no structural investigations on dialkylmalonate- 
substituted aluminium alkoxides were reported until the present work. Only the modification of some metal chlorides or amides with malonates for use as metal-organic chemical vapour deposition (MOCVD) precursors or polymerization catalysts has been reported [13-19].

The use of dialkylmalonates also opens an easy possibility to introduce functional groups, e.g. polymerizable groups for the use as precursors for inorganic-organic hybrid materials with dual network structures [20]. Compared to $\beta$-ketoesters, where ligands such as allyl acetoacetate (aaa-H) or 2-(methacryloyloxy)ethyl acetoacetate (meaa-H) are coordinated to $\mathrm{Ti}, \mathrm{Zr}$ or $\mathrm{Al}$ alkoxides [12, 2124], dialkylmalonates can accommodate two functional groups per ligand and therefore introduce twice as many functionalities. Compared to $\beta$-ketoesterate ligands, a further benefit is that owing to the symmetric nature of malonates, the number of possible stereoisomers is reduced and spectroscopic characterization therefore is eased. For example, one $\mathrm{C}_{3^{-}}$and three $\mathrm{C}_{1^{-}}$-symmetric isomers coexist for the $\beta$-ketoester derivatives $\operatorname{Al}(\beta \text {-ketoesterate })_{3}$. This gives rise to four sets of signals in the NMR spectra, complicating their interpretation [12].

In this contribution, we report our results on the modification of $\mathrm{Al}(\mathrm{OR})_{3}(\mathrm{R}=t \mathrm{Bu}, i \mathrm{Pr}, \mathrm{Et})$ with dimethyl (dmem-H), diethyl (detm-H), di-iso-propyl (diprm-H) and di-tert-butyl (dtbum-H) malonate (Fig. 1).

Formation, structure and stability of dialkylmalonate derivatives were studied, including investigation of transesterification as a possible side reaction, depending on the OR groups of the malonate ligand, the $\mathrm{Al}(\mathrm{OR})_{3}$ precursor and the reaction conditions. The results are compared to analogous reactions with $\beta$-diketones and $\beta$-ketoesters.

\section{Results and discussion}

\section{Al(dialkylmalonate $)_{3}$ complexes}

As expected, dialkylmalonates had a lower reactivity towards aluminium alkoxides compared to $\beta$-ketoesters due to the presence of a second OR substituent. No reaction with $\left[\mathrm{Al}(\mathrm{O} i \mathrm{Pr})_{3}\right]_{4}$ was observed at room temperature.

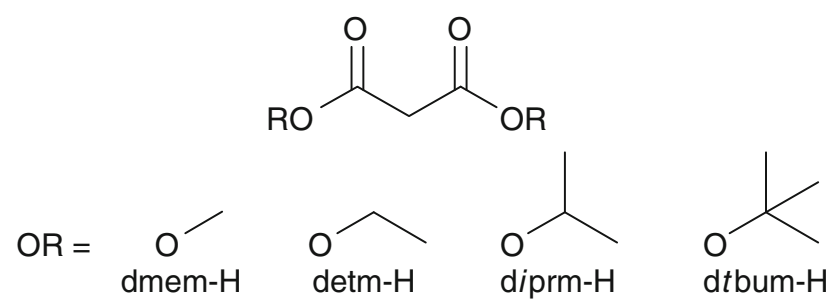

Fig. 1 Dialkylmalonates used for the modification of $\mathrm{Al}(\mathrm{OR})_{3}$
Reaction at higher temperatures led to the desired products, although longer reaction times were necessary.

Monomeric complexes Al(dialkylmalonate) $)_{3}$ (1) were prepared by reacting $\mathrm{Al}(\mathrm{O} i \mathrm{Pr})_{3}$ or $\mathrm{Al}(\mathrm{O} t \mathrm{Bu})_{3}$ with the corresponding dialkylmalonates in a $1: 3$ stoichiometric ratio (Eq. 1). The complexes 1 lack $\mathrm{Al}-\mathrm{OR}$ groups and are therefore not standard sol-gel precursors, but they are important for the complete characterization of the other products with a lower degree of substitution (see below) and also prove the possibility to directly replace $\mathrm{O} i \operatorname{Pr}$ groups at the $\mathrm{Al}$ centre by dialkylmalonate without requiring additional reagents for deprotonation of the malonate.

$$
\mathrm{Al}(\mathrm{OiPr})_{3}+3 \text { (1) }
$$

The complexes $\mathrm{Al}(\mathrm{diprm})_{3}$ (1c) and $\mathrm{Al}(\mathrm{d} t \text { bum })_{3}$ (1d) were obtained by reacting $\mathrm{Al}(\mathrm{O} i \mathrm{Pr})_{3}$ with diprm-H or $\mathrm{d} t$ bum-H in toluene at 60 or $80^{\circ} \mathrm{C}$. The reactions with dmem-H and detm-H were less straightforward and resulted in products giving NMR spectra with multiple, broad and overlapping resonances. A closer look revealed that transesterification, i.e. exchange of the malonate $\mathrm{OR}^{\prime}$ groups with $\mathrm{O} i \mathrm{Pr}$ groups, had taken place concomitantly, which was inter alia indicated by the formation of free diprm-H and coordinated diprm, but formation of $\mathbf{1 a}$ or $\mathbf{1} \mathbf{b}$ could not be confirmed. Transesterification was not quantitative, and malonate species with both $\mathrm{O} i \mathrm{Pr}$ and $\mathrm{OMe} / \mathrm{OEt}$ groups as well as $\mathrm{Al}(\mathrm{OEt})_{x} / \mathrm{Al}(\mathrm{OMe})_{x}$ species were spectroscopically identified. Furthermore, there was no complete substitution and formation of $\mathrm{Al}$ (dialkylmalonate) ${ }_{3}$ species.

Since the degree of oligomerization of $\mathrm{Al}(\mathrm{O} i \mathrm{Pr})_{3}$ in solution is known to be temperature-dependent [25], $\left[\mathrm{Al}(\mathrm{O} i \mathrm{Pr})_{3}\right]_{4}$ was de-oligomerized prior to the reaction with the dialkylmalonates. This strategy was proven successful in the reaction with $\beta$-ketoesters [12]. A solution of $\left[\mathrm{Al}(\mathrm{O} i \mathrm{Pr})_{3}\right]_{4}$ in toluene was thus heated to reflux for 3 days and, after cooling to room temperature, dmem-H or detm-H was added. After stirring overnight at room temperature coordination of the malonate was confirmed by NMR spectroscopy, but again transesterification was observed to a large extent. These results demonstrate that (1) de-oligomerization accelerates substitution of alkoxo groups and enables the reaction at room temperature, but (2) does not prevent transesterifiction. 
Compound 1c also was prepared by an alternative solvent-free reaction procedure, in which $\mathrm{Al}(\mathrm{O} i \mathrm{Pr})_{3}$ was reacted with ten equivalents of diprm-H. Since neither $\left[\mathrm{Al}(\mathrm{OiPr})_{3}\right]_{4}$ nor $\mathrm{Al}(\mathrm{d} i \mathrm{prm})_{3}$ are very soluble in diprm- $\mathrm{H}$ and the reaction mixture stayed heterogeneous at $120^{\circ} \mathrm{C}$, it is supposed that thermally de-oligomerized $\mathrm{Al}(\mathrm{O} i \mathrm{Pr})_{3}$ species were dissolved in diprm- $\mathrm{H}$, where they reacted to give $\mathrm{Al}(\mathrm{diprm})_{3}$, which then precipitated. Of course, monoand disubstituted intermediates also have to be soluble in diprm-H.

To study the influence of the OR groups of $\mathrm{Al}(\mathrm{OR})_{3}$, analogous reactions were carried out starting from $\mathrm{Al}(\mathrm{O} t \mathrm{Bu})_{3}$. As a consequence of the bulkier tert-butoxo groups, dimeric $\left[\mathrm{Al}(\mathrm{O} t \mathrm{Bu})_{3}\right]_{2}$ is the predominant species at room temperature and elevated temperatures, also in solution. As for de-oligomerized $\mathrm{Al}(\mathrm{O} i \mathrm{Pr})_{3}$, coordination of malonate can already be observed at room temperature, although the reaction is slow. To accelerate the reaction, the temperature was raised to $50{ }^{\circ} \mathrm{C}$ and all $\mathrm{Al}$ (malonate) ${ }_{3}$ complexes 1a-1d were obtained under these conditions. This reveals that the bulkiness of the $\mathrm{O} t \mathrm{Bu}$ is overcome by the easier accessibility of the tetrahedral $\mathrm{Al}$ centre in $\left[\mathrm{Al}(\mathrm{O} t \mathrm{Bu})_{3}\right]_{2}$. Compared to $\mathrm{Al}(\mathrm{O} i \mathrm{Pr})_{3}$, transesterification was not observed for $\mathrm{Al}(\mathrm{O} t \mathrm{Bu})_{3}$ in any case, showing that the tendency to undergo transesterification depends on the steric demand of the alkoxo groups.

NMR spectroscopic characterization of 1a-1d in solution $\left(\mathrm{C}_{6} \mathrm{D}_{6}\right.$, toluene- $\left.d_{8}\right)$ confirmed the expected symmetric octahedral structure showing only one signal for $\mathrm{COCHCO}$ in the ${ }^{1} \mathrm{H}(4.81-4.99 \mathrm{ppm})$ and ${ }^{13} \mathrm{C}(66.2-69.0 \mathrm{ppm}) \mathrm{NMR}$ spectra as well as for $C O(175.5-175.9 \mathrm{ppm})$. Interestingly, the signals for $\mathrm{OCH}\left(\mathrm{CH}_{3}\right)_{2}$ in 1c split into two doublets, whereas only one signal for $\mathrm{COOC}\left(\mathrm{CH}_{3}\right)_{3}$ in 1d was observed. No significant influence on the ${ }^{1} \mathrm{H}$ and ${ }^{13} \mathrm{C}$ NMR shifts upon variation of the ester alkoxo group was found. ${ }^{27} \mathrm{Al}$ NMR spectroscopy of 1c additionally confirmed the structure, showing only one sharp signal for octahedrally coordinated $\mathrm{Al}$ at $5.3 \mathrm{ppm}[7]$.

Single crystal X-ray diffraction (XRD) of 1a and 1d (Fig. 2) revealed nearly ideal octahedral coordination around the central aluminium atom, with negligible differences in Al-O bond distances (186.9(1)-189.3(1) pm) and bite angles of the malonates very close to $90^{\circ}$ $\left(90.39(4)-91.36(4)^{\circ}\right)$. Interestingly, the bond distances are distinctly shorter than those observed for $\mathrm{Al}-\mathrm{O}^{\text {ester }}$ bonds in $\mathrm{Al}$ (tert-butyl acetoacetate $)_{3}$ [26] (193.0(2)-195.1(2) pm) and are more in the range of the $\mathrm{Al}-\mathrm{O}^{\mathrm{keto}}$ distances (185.7(2)-186.8(2) pm) in the same complex [27] or in $\mathrm{Al}(\mathrm{acac})_{3}(\mathrm{acac}=$ acetylacetonate $)(188.0(2) \mathrm{pm})$ [27].

In both complexes, two of the metallacycles formed by the coordination of the malonate ligand exhibit an envelope-like conformation with $\mathrm{Al}$ deviating from the $\mathrm{O}-\mathrm{C}-\mathrm{CH}-\mathrm{C}-\mathrm{O}$ plane, whereas the third metallacycle

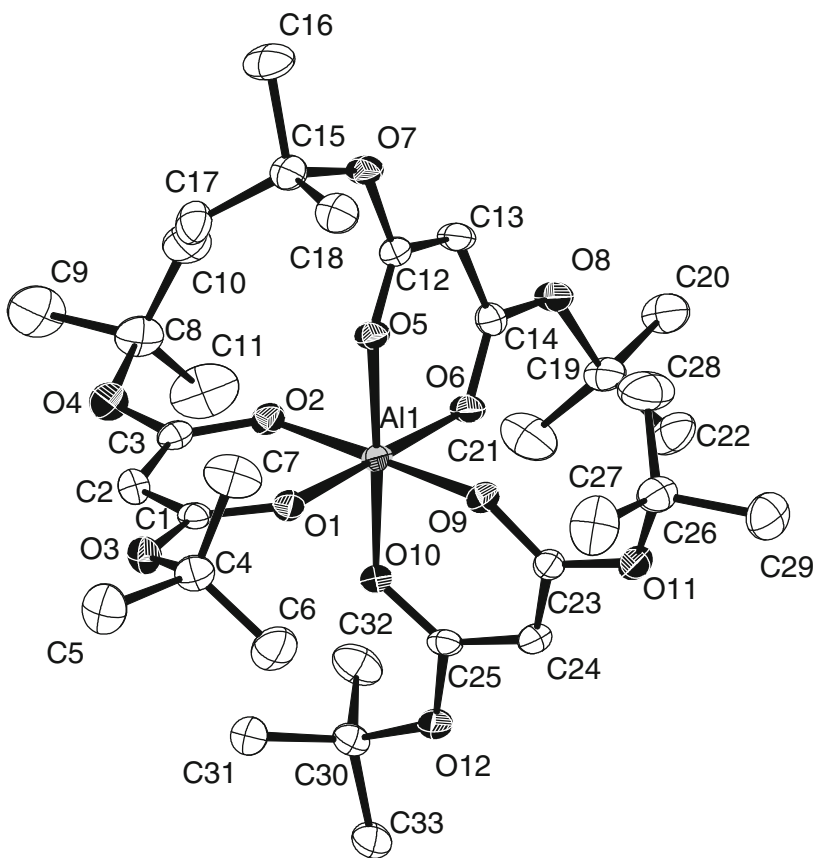

Fig. 2 Molecular structure of 1d (hydrogen atoms omitted for clarity)

exhibits a nearly planar or slightly twisted conformation. The same combination of ligand conformations was observed for the mentioned $\beta$-diketonate and $\beta$-ketoesterate derivatives [26, 27].

\section{$\mathrm{Al}_{2}(\mathrm{OiPr})_{4}(\text { dialkylmalonate })_{2}$ complexes}

Modification of $\mathrm{Al}(\mathrm{O} i \mathrm{Pr})_{3}$ with dmem- $\mathrm{H}$ and detm- $\mathrm{H}$ in a stoichiometric ratio of $\mathrm{Al} /$ malonate $=1: 1$ also gave product mixtures through transesterification at the ester group as well as the $\mathrm{Al}$ centre. For the reaction with one equivalent of diprm-H or $\mathrm{d} t$ bum- $\mathrm{H}$ per $\mathrm{Al}$, complexes of the composition $\mathrm{Al}_{2}(\mathrm{O} i \operatorname{Pr})_{4}(\text { malonate })_{2}(\mathbf{2} \mathbf{c}$, malonate $=$ diprm; 2d, malonate $=\mathrm{d} t$ bum) were obtained. Similar to analogous $\beta$-ketoesterate-substituted complexes [12], higher reaction temperatures and longer reaction times had to be applied.

The structure of $\mathbf{2}$ consists of one tetrahedrally coordinated $\mathrm{Al}$ centre surrounded by two terminal and two bridging $\mathrm{O} i \mathrm{Pr}$ groups, whereas the second $\mathrm{Al}$ centre is octahedrally coordinated by two bridging $\mathrm{O} i \mathrm{Pr}$ groups and two chelating malonate ligands (Fig. 3).

Contrary to $\beta$-ketoesterate-substituted complexes only one isomer is expected because of the symmetric dialkylmalonate ligands. This was confirmed by NMR spectroscopy, showing only one signal for the COCHCO proton at 4.83 (2c) and 4.68 (2d) ppm, respectively. The methine protons for the terminal ( $\mathrm{t}$ ) and bridging (b) $\mathrm{AlO} i \operatorname{Pr}$ groups are clearly distinguished at $4.26(\mathrm{t})$ and 4.52 (b) ppm (2c) and 4.34 (t) and 4.52 (b) ppm (2d), 


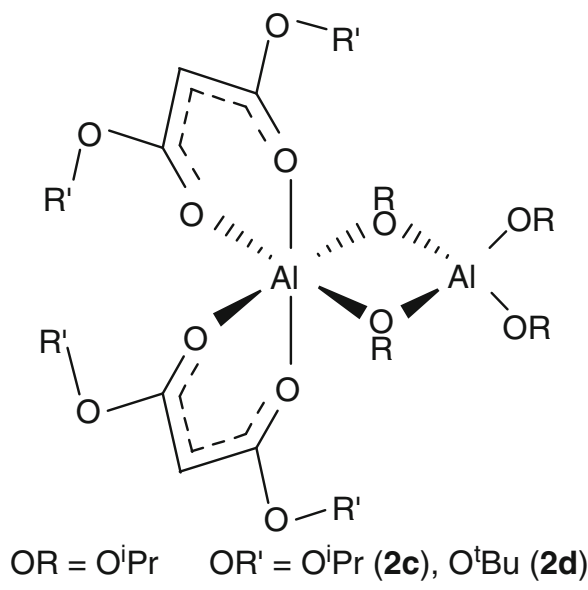

Fig. 3 Schematic structure of $\mathrm{Al}_{2}(\mathrm{O} i \mathrm{Pr})_{4}(\text { malonate) })_{2}$ (malonate $=\operatorname{diprm}(\mathbf{2 c})$ and $\mathrm{d} t$ bum $(\mathbf{2 d}))$

respectively. The ${ }^{13} \mathrm{C}$ NMR resonances $(63.5(\mathrm{t})$ and 66.3 (b) for $2 \mathrm{c}, 63.5$ (t) and 65.8 (b) for $2 \mathrm{~d}$ ) also confirm the binuclear structure. The methyl protons of the bridging $\mathrm{O} i \mathrm{Pr}$ groups give rise to two signals. This splitting might result from different environments caused by hindered rotation, viz. being directed to the octahedrally or tetrahedrally coordinated $\mathrm{Al}$ centre.

The signals for the malonate- $\mathrm{O} i \operatorname{Pr}(\mathbf{2 c})$ and $\mathrm{O} t \mathrm{Bu}(\mathbf{2 d})$ methyl protons also split into four and two signals, respectively. This indicates different environments of the malonate ester groups trans to another carboxylic group or trans to a bridging $\mathrm{O} i \mathrm{Pr}$ group. For $\mathbf{2 c}$ two signals for the malonate methine protons were also observed (4.96 and $5.41 \mathrm{ppm})$. Additionally, the $\mathrm{OCHC}\left(\mathrm{CH}_{3}\right)_{2}$ methyl protons in $2 \mathbf{c}$ for each of these two types of ester $\mathrm{O} i \mathrm{Pr}$ groups further give two doublets, indicating a preferential orientation of the $\mathrm{O} i \mathrm{Pr}$ groups which results in two nonequivalent environments for each methyl group.

Exchange spectroscopy (EXSY) spectra show exchange of the signals for the bridging/terminal $\mathrm{O} i \mathrm{Pr}$ groups and additionally for the two $\mathrm{O} i \mathrm{Pr}$ (in 2c) or $\mathrm{O} t \mathrm{Bu}$ (in 2d) groups of the malonate ligands (Fig. 4). Exchange between $\mathrm{Al}-\mathrm{O} i \mathrm{Pr}$ and malonate-OR groups was not observed.

${ }^{27} \mathrm{Al}$ NMR spectra of $\mathbf{2 c}$ and $2 d$ (Fig. 5) additionally supported the structure. Both spectra showed a broad signal assigned to tetrahedrally coordinated $\mathrm{Al}$ between 130 and $20 \mathrm{ppm}$ with maxima at about 65 and $80 \mathrm{ppm}$, respectively, and one sharp signal at 5.1 or $4.8 \mathrm{ppm}$, assigned to octahedrally coordinated $\mathrm{Al}$ [7]. Integration of the signals revealed almost the expected 1:1 ratio, although integration is somewhat difficult because of the broad signal for tetrahedrally coordinated Al.

The single crystal structure analysis of $\mathbf{2 d}$ was in agreement with that derived from NMR spectra in solution (Fig. 6). The bite angles for the two malonate ligands

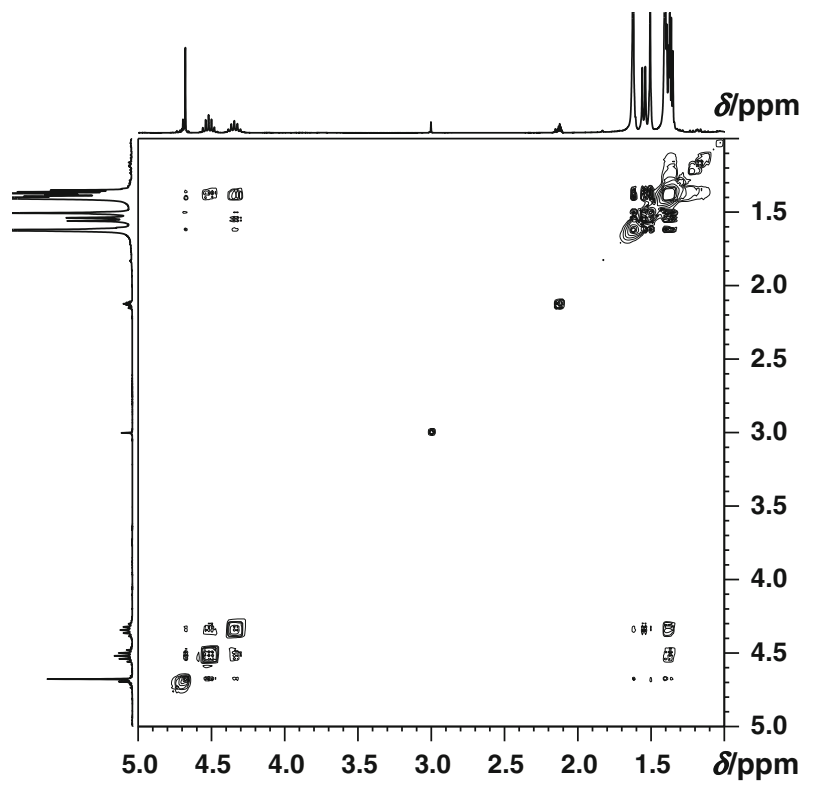

Fig. 4 EXSY spectrum of 2d

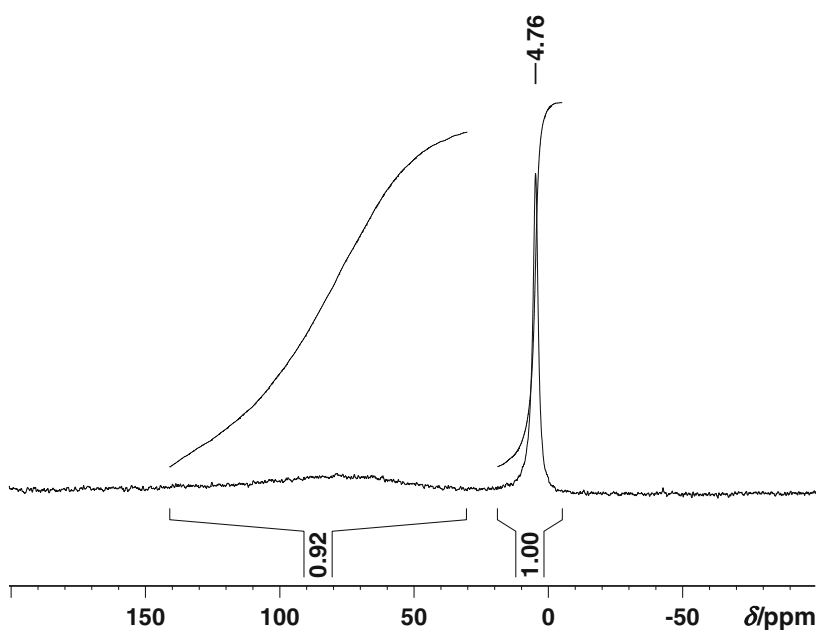

Fig. $5{ }^{27} \mathrm{Al}$ NMR spectrum of $\mathbf{2 d}$ (in toluene- $d_{8}$ )

at the octahedral $\mathrm{Al}$ centre are $90.29(7)^{\circ}$ and $90.39(7)^{\circ}$. One of the malonate ligands again shows a slightly envelope-like conformation, whereas the other one is nearly planar. Interestingly, no trans influence on the $\mathrm{Al}-\mathrm{O}$ bond distances (188.26(15)-188.98(17) pm) was observed for the malonate ligands. The angle between the two bridging $\mathrm{O} i \mathrm{Pr}$ groups $\mathrm{O}(3)-\mathrm{Al}(2)-\mathrm{O}(4)$ at the octahedral $\mathrm{Al}$ centre is only $76.61(7)^{\circ}$ and leads to a distortion of the coordination octahedron. As expected, the bond distances $\mathrm{Al}(2)-\mathrm{O}(3)$ and $\mathrm{Al}(2)-\mathrm{O}(4)$ between the octahedral $\mathrm{Al}$ centre and the bridging $\mathrm{O} i \mathrm{Pr}$ are significantly longer than those from the tetrahedral $\mathrm{Al}$ centre to the bridging units, viz. 190.34(17) and 190.21(16) pm vs. 179.78(16) $(\mathrm{Al}(1)-\mathrm{O}(3))$ and 179.13(17) $(\mathrm{Al}(1)-\mathrm{O}(4)) \mathrm{pm}$. 


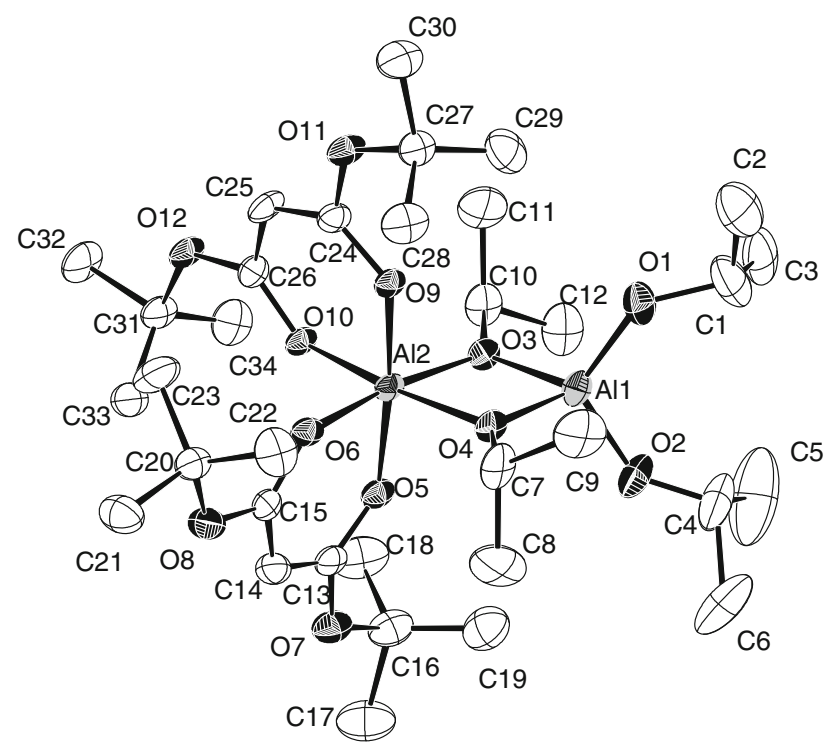

Fig. 6 Molecular structure of 2d (hydrogen atoms omitted for clarity)

In addition, the $\mathrm{O}(3)-\mathrm{Al}(1)-\mathrm{O}(4)$ angle at the tetrahedral Al centre $\left(82.17(7)^{\circ}\right)$ is larger than that at the octahedral centre, as expected due to the different coordination geometry. Both bond distances to the terminal $\mathrm{O} i \mathrm{Pr}$ groups $\mathrm{Al}(1)-\mathrm{O}(1)$ and $\mathrm{Al}(1)-\mathrm{O}(2)$ of $169.82(19)$ and $169.78(18) \mathrm{pm}$, respectively, are significantly shorter than those to the bridging $\mathrm{O} i \mathrm{Pr}$ groups. Comparison with $\mathrm{Al}_{2}(\mathrm{O} i \mathrm{Pr})_{4}$ (tert-butyl acetoacetate $)_{2}$ shows similar bond distances and angles, with the bond distances $\mathrm{Al}-\mathrm{O}^{\text {malonate }}$ lying between those for Al-O ${ }^{\text {ester }}(190.4(4)-192.6(4) \mathrm{pm})$ and $\mathrm{Al}-\mathrm{O}^{\text {keto }}(185.0(4)-187.2(4) \mathrm{pm})$. The ketoesterate ligands in this structure also show both envelope and twisted conformation [12].

The structure of $\mathbf{2 d}$ shows two different environments for the methyl groups of the bridging OiPr groups, which correlates with the observation of two signals in the solution ${ }^{1} \mathrm{H}$ NMR spectrum and therefore indicates that these $\mathrm{O} i \mathrm{Pr}$ groups do not rotate freely in solution.

\section{$\mathrm{Al}_{2}(\mathrm{OiPr})_{2}(\text { diprm })_{4}$}

Storage of 2c, a colourless oil, resulted in the formation of colourless crystals. Single crystal XRD surprisingly revealed that $\mathrm{Al}_{2}(\mathrm{O} i \mathrm{Pr})_{2}(\mathrm{diprm})_{4}$ (3c) had crystallized rather than 2c (Fig. 7). This is of special interest, since attempts to prepare $3 \mathbf{c}$ directly from $\mathrm{Al}(\mathrm{O} i \mathrm{Pr})_{3}$ with two equivalents of diprm-H at $100{ }^{\circ} \mathrm{C}$ had failed and only mixtures of $\mathrm{Al}_{2}(\mathrm{O} i \mathrm{Pr})_{4}(\mathrm{~d} i \mathrm{prm})_{2}(\mathbf{2 c})$ and $\mathrm{Al}(\mathrm{d} i \mathrm{prm})_{3}$ (1c) had been obtained. $\mathrm{Al}_{2}(\mathrm{OR})_{2}(\beta \text {-diketonate })_{4}$ derivatives were also reported to disproportionate to $\mathrm{Al}_{2}(\mathrm{OR})_{4}(\beta$ diketonate $)_{2}$ and $\mathrm{Al}(\beta \text {-diketonate })_{3}$ [8]. Only one structure analysis has been reported, viz. that of $\mathrm{Al}_{2}(\mathrm{O} i \mathrm{Pr})_{2}(3,5-$

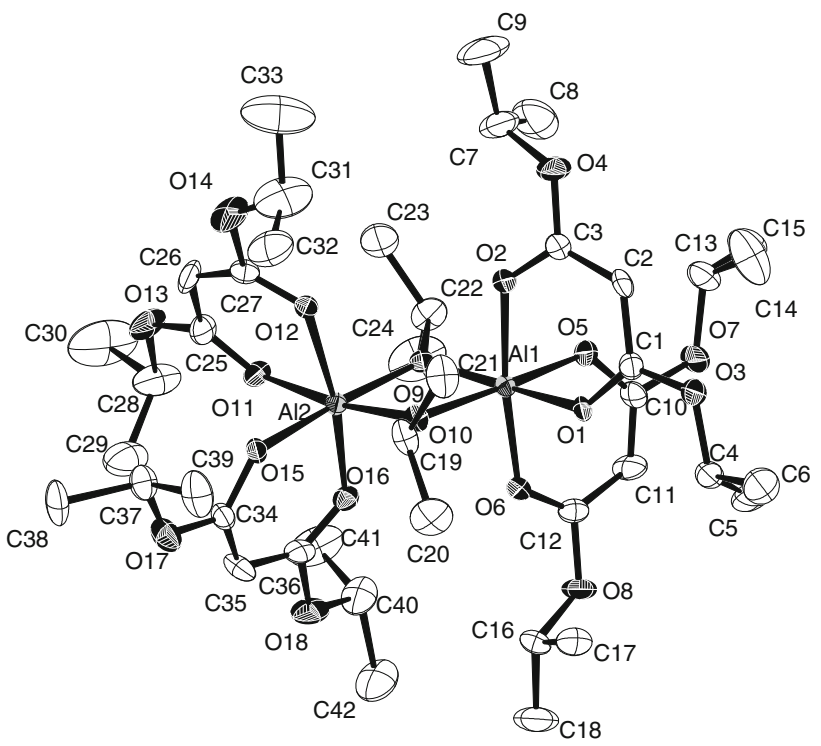

Fig. 7 Molecular structure of $\mathbf{3 c}$ (hydrogen atoms omitted for clarity)

heptandionate $)_{4}[10] . \quad \beta$-Ketoesterate derivatives of the general formula $\mathrm{Al}_{2}(\mathrm{OR})_{2}(\beta \text {-ketoesterate })_{4}$ were not obtained [12].

Other products formed during this rearrangement could not be identified by means of the used spectroscopic or crystallographic methods. The rearrangement occurred only upon storage of isolated $\mathbf{2 c}$, whereas storage of a solution of $\mathbf{2 c}$ in toluene did not show any changes after 1 month. Therefore the rearrangement could not be monitored by NMR spectroscopy.

The structure of $\mathbf{3 c}$ can formally be derived from that of 2 by substituting the two terminal O $i$ Pr ligands with two malonate ligands and thus converting the tetrahedral aluminium centre in an octahedrally coordinated. Al-O bond distances to the malonate ligands are 190.1(4)192.5(4) pm and the bite angles 88.8(2)-89.3(2) ${ }^{\circ}$. At each Al centre, one coordinated malonate ligand has an envelope-like conformation, whereas the other is nearly planar (as in 1c). The angles between the $\mathrm{Al}$ centre and the bridging $\mathrm{O} i \mathrm{Pr}$ groups are $77.6(2)^{\circ}(\mathrm{O}(9)-\mathrm{Al}(1)-\mathrm{O}(10))$ and $77.9(2)^{\circ}(\mathrm{O}(9)-\mathrm{Al}(2)-\mathrm{O}(10))$ and the corresponding $\mathrm{Al}-\mathrm{O}$ bond distances 186.7(4)-188.7(4) pm. Both $\mathrm{C}-\mathrm{O}$ bonds of the bridging $\mathrm{O} i \mathrm{Pr}$ groups are bent towards the same side of the $\mathrm{Al}_{2} \mathrm{O}_{2}$ plane, resulting in one methyl group being closer and the other more distant to the plane, supporting the observation of two methyl signals in the ${ }^{1} \mathrm{H}$ and ${ }^{13} \mathrm{C}$ NMR spectra. EXSY spectroscopy reveals signals corresponding to exchange between the two AlOCHMe $\mathrm{Me}_{2}$ protons, indicating a fluctuating behaviour of these groups.

It is also interesting to mention that from the two possible geometric isomers, viz. meso and $d, l$ (Fig. 8), the $d, l$ form crystallizes at room temperature, in contrast to the 


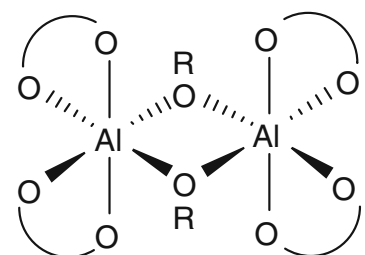

meso

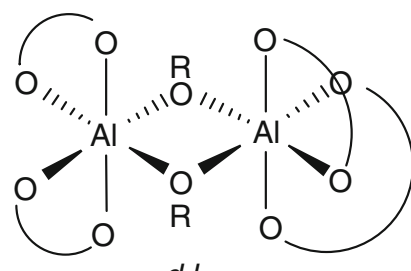

$d, I$
Fig. 8 Schematic representation of meso and $d, l$ geometries for $\mathrm{Al}_{2}(\mathrm{OR})_{2}$ (malonate $)_{4}$ complexes

known structure of $\mathrm{Al}_{2}(\mathrm{O} i \mathrm{Pr})_{2}$ (3,5-heptandionate $)_{4}$, which crystallized in the meso form $[8,10]$.

NMR spectroscopy confirmed the conversion of $\mathbf{2 c}$ into 3c. The spectra of $\mathbf{3 c}$ were completely different compared to that of 2c. The ${ }^{1} \mathrm{H}$ NMR signals for $\mathrm{COCHCO}$ and $\mathrm{AlOC} H\left(\mathrm{CH}_{3}\right)_{2}$ were both shifted to higher ppm values, viz. 4.91 and $4.76 \mathrm{ppm}$, and only one quintet for $\mathrm{AlOCH}\left(\mathrm{CH}_{3}\right)_{2}$ was observed. The signals for $\mathrm{COOCH}\left(\mathrm{CH}_{3}\right)_{2}$ split into two slightly overlapping quintets at 5.17 and 5.28 ppm, caused by the different environments of the malonate OiPr groups directed to and away from the second $\mathrm{Al}$ centre. Analogous to $\mathbf{2 c}$, the signals for the malonate methyl groups split into four doublets (two of them overlapping), again indicating preferential orientation of the malonate $\mathrm{O} i \mathrm{Pr}$ groups with non-equivalent environments for the methyl groups. The methyl proton resonances for the bridging $\mathrm{AlO} i \mathrm{Pr}$ groups also split into two doublets, indicating hindered rotation of these groups and two different environments for the methyl groups. This confirms that the dimeric structure with two $\mathrm{Al}$ centres, each coordinated by two malonate ligands and bridged by two $\mathrm{O} i \mathrm{Pr}$ groups, is retained in solution, further supported by the ${ }^{27} \mathrm{Al}$ NMR data, showing only a signal for octahedrally coordinated $\mathrm{Al}$ centres at $3.5 \mathrm{ppm}$.

\section{$\mathrm{Al}_{3}(\mathrm{OH})_{2}(\mathrm{OEt})_{3}(\mathrm{detm})_{5}$}

Since the preparation of $\mathrm{Al}(\mathrm{detm})_{3}(\mathbf{1 b})$ from $\mathrm{Al}(\mathrm{O} i \mathrm{Pr})_{3}$ and detm-H failed due to transesterification, an alternative preparative route was explored to avoid transesterification. Since $\mathrm{Al}(\mathrm{OEt})_{3}$ is oligomeric, it is only sparingly soluble in most organic solvents, including toluene. However, at least partial thermal de-oligomerization and subsequent partial solubility was expected, as for $\mathrm{Al}(\mathrm{O} i \mathrm{Pr})_{3}$, and therefore $\mathrm{Al}(\mathrm{OEt})_{3}$, dispersed in toluene, was reacted with three equiv. of detm-H at $90{ }^{\circ} \mathrm{C}$. The solution immediately cleared upon heating. Monitoring of the reaction by ${ }^{1} \mathrm{H}$ NMR spectroscopy clearly revealed coordination of the malonate, but significant differences to the spectrum of $\mathbf{1 b}$ were observed and greater proportions of unreacted detm-H were detected. Removal of all volatiles and storage of the obtained oil for a few days at room temperature yielded crystals, which turned out to be $\mathrm{Al}_{3}(\mathrm{OH})(\mathrm{OEt})_{3}(\operatorname{detm})_{5}$ (4) (Fig. 9).

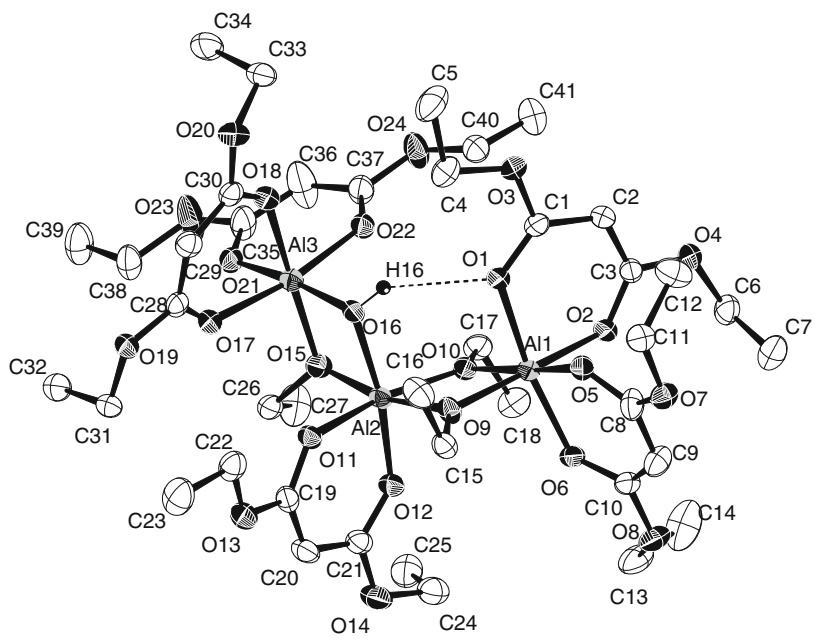

Fig. 9 Molecular structure of 4 (C-bonded hydrogen atoms omitted for clarity)

The crystal structure of $\mathbf{4}$ shows three octahedrally coordinated $\mathrm{Al}$ centres. The two terminal $\mathrm{Al}$ centres are coordinated by two malonate ligands each, whereas the central one is coordinated only by one malonate, leading to an overall $\mathrm{Al} / \mathrm{malonate}$ ratio of 3:5. One terminal $\mathrm{Al}$ centre $(\mathrm{Al}(1))$ is connected to the central one $(\mathrm{Al}(2))$ by bridging OEt groups, while the second terminal $\mathrm{Al}$ centre $(\mathrm{Al}(3))$ is connected by only one bridging OEt group and a bridging hydroxo group. Again, one of the malonates at each terminal Al centre has an envelope conformation and the other is nearly planar, as is the malonate ligand at the central $\mathrm{Al}$ atom. No trans influence was observed, resulting in Al-O(malonate) bond distances of 188.57(11)-191.45 (11) pm, except for $\mathrm{Al}(1)-\mathrm{O}(1)$, which is $194.76(11) \mathrm{pm}$. This slight elongation is traced back to a hydrogen bond between the hydroxo hydrogen $\mathrm{H}(16)$ and $\mathrm{O}(1)$ of $220.8(16) \mathrm{pm}$. The bite angles of the malonates are between $88.29(5)^{\circ}$ and $89.56(5)^{\circ}$. The bond distances between the $\mathrm{Al}$ centres and the bridging $\mathrm{O}$ atoms are in the range 184.42(11)-189.57(11) pm, not showing significant differences for the hydroxo group compared to the OEt groups.

All resonances of the ${ }^{1} \mathrm{H}$ and ${ }^{13} \mathrm{C}$ NMR spectra could be assigned based on the structure, but no resonance for $\mathrm{Al}-\mathrm{O} H$ was observed. Only one resonance for the methyl and two for the methylene protons for all three AlOEt groups were observed at 1.33 and 3.72-3.84/4.43$4.60 \mathrm{ppm}$ in the ${ }^{1} \mathrm{H}$ NMR spectrum. The ${ }^{13} \mathrm{C}$ NMR spectrum showed only two signals at 18.4 and $56.6 \mathrm{ppm}$ for the methyl and methylene carbons of the AlOEt groups. The methyl groups of the five detm ligands resulted in two triplets of equal intensity at 0.99 and $1.14 \mathrm{ppm}$ in the ${ }^{1} \mathrm{H}$ NMR spectrum. In the ${ }^{13} \mathrm{C}$ NMR spectrum, the malonate OEt groups exhibited two resonances each for the methyl 
and methylene carbon at $14.4 / 14.6$, and at $60.0 / 60.1 \mathrm{ppm}$. Single resonances were observed for $\mathrm{COCHCO}$ in the ${ }^{1} \mathrm{H}$ (4.91 ppm) and ${ }^{13} \mathrm{C}$ (66.4 ppm) NMR spectra as well as for CO (175.4 ppm). EXSY spectra indicate exchange between the signals at 3.72-3.84 and 3.92-4.12 ppm and between the signals at 3.92-4.12 and 4.43-4.60 ppm. Since the signal at 3.72-3.84 ppm originates only from $\mathrm{AlOCH}_{2} \mathrm{Me}$ and the signal at $4.43-4.60 \mathrm{ppm}$ only from $\mathrm{COOCH}_{2} \mathrm{Me}$, whereas the signals at 3.92-4.12 ppm results from overlapping signals of both types of OEt groups and no exchange between the signals at 3.72-3.84 and 4.43-4.60 ppm was observed, it is assumed that exchange happens only between $\mathrm{Al}-\mathrm{OEt}$ groups or between malonate-OR groups, but not between $\mathrm{Al}-$ and malonate-OR groups. ${ }^{27} \mathrm{Al}$ NMR spectroscopy showed only one signal at $5.9 \mathrm{ppm}$, in line with the existence of only octahedrally coordinated $\mathrm{Al}$ [7]. A slight broadening of the signal compared to those for octahedral $\mathrm{Al}$ in $\mathbf{1 c}, \mathbf{2 c}$, and $\mathbf{2 d}$ was observed and is probably caused by the coexistence of three different $\mathrm{Al}$ centres.

At present, the origin of the hydroxo group is not clear, but it is strongly believed that it results from cleavage of an OEt group with transfer of a proton to the oxygen and release of ethylene. The other possibility, partial hydrolysis during the reaction or of the used $\mathrm{Al}(\mathrm{OEt})_{3}$, can be excluded since all operations were carefully carried out under exclusion of moisture and the compound was synthesized reproducibly. Furthermore, no partial hydrolyzed species were observed in other experiments starting from $\mathrm{Al}(\mathrm{OEt})_{3}$ or another aluminium alkoxide. Formation of $\mathbf{4}$ was also observed in a different experiment without the use of $\mathrm{Al}(\mathrm{OEt})_{3}$. During attempts to crystallize $\mathrm{Al}(\mathrm{detm})_{3}$ (1) directly from the reaction solution of $\mathrm{Al}(\mathrm{O} t \mathrm{Bu})_{3}$ and detm-H in toluene, which contained $\mathrm{Al}(\mathrm{detm})_{3}(\mathbf{1 b})$, liberated tert-butanol and some unreacted detm-H, formation of $\mathbf{4}$ was also observed after some weeks by ${ }^{1} \mathrm{H}$ NMR spectroscopy. This observation proves that (1) the use of $\mathrm{Al}(\mathrm{OEt})_{3}$ is not essential for the formation of $\mathbf{4}$ and (2) $\mathbf{4}$ is a stable compound. This also supports the postulated cleavage of an OEt group. Furthermore, the cleavage of $\mathrm{Al}-\mathrm{OR}$ groups to give $\mathrm{Al}-\mathrm{OH}$ and olefins was confirmed for the thermal decomposition of aluminium alkoxides, including $\mathrm{Al}(\mathrm{OEt})_{3}$. Although this reaction was observed at higher temperatures only, it proves that the postulated reaction is in principle possible [28].

\section{Conclusions}

In this work it was shown that dialkylmalonates are versatile ligands for the modification of $\mathrm{Al}$ alkoxides and are a good alternative to $\beta$-diketone or $\beta$-ketoester derivatives, although ligand substitution requires higher reaction temperatures and longer reaction times due to the fact that deprotonation of the malonic esters is less favourable.
Products with an Al/malonate ratio of 1:3 (1c), 1:2 (3c) and 1:1 (2c) were obtained for the reaction of $\mathrm{Al}(\mathrm{O} i \mathrm{Pr})_{3}$ with diprm-H. However, 3c was not obtained by the direct reaction of $\mathrm{Al}$ alkoxide with two equivalents of malonate but formed spontaneously from $\mathbf{2 c}$ upon storage. This is of particular interest, since analogous $\beta$-diketonate or $\beta$-ketoesterate derivatives were reported to be unstable and to decompose to give $\mathrm{Al}(\beta \text {-diketonate })_{3}$ and $\mathrm{Al}_{2}(\mathrm{O} i \mathrm{Pr})_{4}(\beta$ diketonate $)_{2}$ upon storage in solution at room temperature [8]. Complexes $\mathbf{2 c}$ and $\mathbf{2 d}$ with an $\mathrm{Al} /$ malonate ratio of $1: 1$ have analogous structures to the corresponding $\beta$-ketoester derivatives [12], i.e. they are binuclear complexes with one octahedrally coordinated $\mathrm{Al}$ centre bearing two malonate ligands connected by two bridging $\mathrm{O} i \mathrm{Pr}$ groups to the second, tetrahedrally coordinated $\mathrm{Al}$ centre, bearing additional OiPr groups. $\mathrm{Al}_{2}(\mathrm{O} i \mathrm{Pr})_{2}(\mathrm{~d} i \mathrm{prm})_{4}(\mathbf{3 c})$ is a $\mathrm{C}_{2}$-symmetric dimer, again analogous to a known $\beta$-diketonate derivative [10], with two octahedrally coordinated $\mathrm{Al}$ centres.

Modification with dmem-H or detm-H resulted in partial transesterification in the case of $\mathrm{Al}(\mathrm{O} i \mathrm{Pr})_{3}$, but not with $\mathrm{Al}(\mathrm{O} t \mathrm{Bu})_{3}$. This leads to the conclusion that the tendency to undergo transesterification depends on the malonate as well as on the alkoxo groups. The use of $\mathrm{Al}(\mathrm{O} t \mathrm{Bu})_{3}$ also allowed us to obtain $\mathrm{Al}$ (malonate) ${ }_{3}$ complexes for all ligands used (1a-1d), but no products with a stoichiometric ratio of $\mathrm{Al} /$ malonate $=1: 1$ or $1: 2$ were obtained. This indicates that the $\mathrm{O} t \mathrm{Bu}$ group is sterically too demanding to enable formation of $\mathrm{Al}-\mathrm{O} t \mathrm{Bu}-\mathrm{Al}$ bridges, which are necessary to stabilize substitution products by means of coordination expansion.

Finally, the unexpected product $\mathrm{Al}_{3}(\mathrm{OH})(\mathrm{OEt})_{3}(\operatorname{detm})_{5}$ (4) was obtained, bearing an $\mathrm{AlOH}$ group, most likely formed by scission of an OEt group. This is supported by the fact that $\mathbf{4}$ was obtained by two independent experiments.

\section{Experimental}

All operations were carried out in moisture- and oxygenfree atmosphere of dry argon by using standard Schlenk or glove box techniques. $\mathrm{Al}(\mathrm{OEt})_{3}$ (Aldrich, 97\%), $\mathrm{Al}(\mathrm{O} i \mathrm{Pr})_{3}$ (Aldrich, $98+\%), \mathrm{Al}(\mathrm{O} t \mathrm{Bu})_{3}$ (Aldrich, techn.), dimethyl malonate (dmem-H, Aldrich, 98\%), diethyl malonate (detm-H, Fluka, $\geq 99 \%$ ), di-iso-propyl malonate (diprm-H, Aldrich, 99\%) and di-tert-butyl malonate (dtbum- $\mathrm{H}$, Aldrich, 98\%) were used as received. All solvents were dried and purified by standard techniques [29]. $\mathrm{C}_{6} \mathrm{D}_{6}$ (euriso-top, 99.5\%) and toluene- $d_{8}$ (euriso-top, 99.6\%,) used for NMR experiments were dried over $3-\AA$ molecular sieves and degassed.

1D ${ }^{1} \mathrm{H}$ and ${ }^{13} \mathrm{C}$ NMR spectra were recorded on a Bruker AVANCE 250 spectrometer $\left(250.13 \mathrm{MHz}\left({ }^{1} \mathrm{H}\right), 62.86\right.$ $\left.\mathrm{MHz}\left({ }^{13} \mathrm{C}\right)\right)$ and ${ }^{27} \mathrm{Al}$ and $2 \mathrm{D}$ NMR spectra on a Bruker 
AVANCE 300 spectrometer $\left(300.13 \mathrm{MHz}\left({ }^{1} \mathrm{H}\right), 75.47\right.$ MHz $\left.\left({ }^{13} \mathrm{C}\right), 78.21 \mathrm{MHz}\left({ }^{27} \mathrm{Al}\right)\right)$. Both spectrometers were equipped with a $5-\mathrm{mm}$ broadband probe head and a $z$-gradient unit. Correlated spectroscopy (COSY), heteronuclear single quantum correlation (HSQC), heteronuclear multiple-bond correlation (HMBC, evolution delay for long range coupling $100 \mathrm{~ms}$ ) and exchange spectroscopy $\left(\mathrm{EXSY}, t_{\text {mix }}=1.2 \mathrm{~s}\right)$ were measured with Bruker standard pulse sequences. $J$ values are given in $\mathrm{Hz}$. The ${ }^{27} \mathrm{Al}$ NMR signals were referenced externally against a $2 \mathrm{M}$ solution of $\mathrm{AlCl}_{3}$ in water $(0 \mathrm{ppm})$. Superscript (t) and (b) are used to indicate terminal or bridging binding of $\mathrm{OR}$ groups.

As a result of the instability of compounds 2-4 towards moisture, elemental analyses were not meaningful and were not included. Purity of the compounds was determined by NMR spectroscopy and confirmed by single crystal XRD if suitable crystals were obtained.

\section{Tris(dimethylmalonato)aluminum}

(1a, $\left.\mathrm{Al}\left[\mathrm{CH}\left(\mathrm{COOCH}_{3}\right)_{2}\right]_{3}\right)$

$\mathrm{Al}(\mathrm{O} t \mathrm{Bu})_{3}(0.498 \mathrm{~g}, 2.02 \mathrm{mmol})$ was dissolved in $7 \mathrm{~cm}^{3}$ of toluene at room temperature and $0.69 \mathrm{~cm}^{3}(0.798 \mathrm{~g}$, $6.04 \mathrm{mmol})$ of dmem- $\mathrm{H}$ was added under stirring. The reaction mixture was stirred at room temperature for 6 days and at $50{ }^{\circ} \mathrm{C}$ for 2 days. $\mathrm{Al}(\mathrm{dmem})_{3}(0.801 \mathrm{~g}, 94 \%)$ was obtained as a colourless crystalline precipitate after removal of volatiles and drying in vacuo. ${ }^{1} \mathrm{H}$ NMR (toluene- $d_{8}$, $\left.20^{\circ} \mathrm{C}\right): \delta=4.91(\mathrm{~s}, 3 \mathrm{H}, \mathrm{COCHCO}), 3.48(\mathrm{~s}, 18 \mathrm{H}$, $\left.\mathrm{COOCH}_{3}\right)$ ppm; ${ }^{13} \mathrm{C}\left\{{ }^{1} \mathrm{H}\right\}$ NMR (toluene- $d_{8}, 20{ }^{\circ} \mathrm{C}$ ): $\delta=175.8(\mathrm{CO}), 66.2(\mathrm{COCHCO}), 51.1\left(\mathrm{COOCH}_{3}\right) \mathrm{ppm}$.

\section{Tris(diethylmalonato)aluminum}

(1b, $\left.\mathrm{Al}\left[\mathrm{CH}\left(\mathrm{COOCH}_{2} \mathrm{CH}_{3}\right)_{2}\right]_{3}\right)$

$\mathrm{Al}(\mathrm{O} t \mathrm{Bu})_{3}(0.498 \mathrm{~g}, 2.02 \mathrm{mmol})$ was dissolved in $5 \mathrm{~cm}^{3}$ of toluene at room temperature and $0.92 \mathrm{~cm}^{3}(0.971 \mathrm{~g}$, $6.06 \mathrm{mmol}$ ) of detm-H was added under stirring. The reaction mixture was stirred at room temperature for 11 days and at $50{ }^{\circ} \mathrm{C}$ for 3 days. $\mathrm{Al}(\operatorname{detm})_{3}(0.967 \mathrm{~g}, 95 \%)$ was obtained as a colourless solid after removal of volatiles and drying in vacuo. ${ }^{1} \mathrm{H}$ NMR $\left(\mathrm{C}_{6} \mathrm{D}_{6}, 20{ }^{\circ} \mathrm{C}\right): \delta=4.99$ (s, $3 \mathrm{H}, \mathrm{COCHCO}), 4.18-3.96\left(\mathrm{~m}, 12 \mathrm{H}, \mathrm{COOCH}_{2} \mathrm{Me}\right), 1.00$ (t, $\left.J=7.0 \mathrm{~Hz}, 18 \mathrm{H}, \mathrm{COOCH}_{2} \mathrm{CH}_{3}\right) \mathrm{ppm} ;{ }^{13} \mathrm{C}\left\{{ }^{1} \mathrm{H}\right\} \mathrm{NMR}$ $\left(\mathrm{C}_{6} \mathrm{D}_{6}, 20{ }^{\circ} \mathrm{C}\right): \delta=175.9(\mathrm{CO}), 67.1$ (COCHCO), 60.8 $\left(\mathrm{COOCH}_{2} \mathrm{Me}\right), 14.6\left(\mathrm{COOCH}_{2} \mathrm{CH}_{3}\right) \mathrm{ppm}$.

\section{Tris(di-iso-propylmalonato)aluminum}

(1c, $\left.\mathrm{Al}\left[\mathrm{CH}\left\{\mathrm{COOCH}\left(\mathrm{CH}_{3}\right)_{2}\right\}_{2}\right]_{3}\right)$

Method A: $\mathrm{Al}(\mathrm{O} t \mathrm{Bu})_{3}(0.502 \mathrm{~g}, 2.04 \mathrm{mmol})$ was dissolved in $7 \mathrm{~cm}^{3}$ of toluene at room temperature and $1.16 \mathrm{~cm}^{3}$ $(1.150 \mathrm{~g}, 6.11 \mathrm{mmol})$ of diprm-H was added under stirring. The reaction mixture was stirred at room temperature for 3 days and at $50{ }^{\circ} \mathrm{C}$ for 7 days. The solvent volume was reduced and $\mathrm{Al}(\mathrm{diprm})_{3}(0.804 \mathrm{~g}, 67 \%)$ obtained as colourless crystals after recrystallization and storage for few days at room temperature.

Method B: $\mathrm{Al}(\mathrm{OiPr})_{3}(0.994 \mathrm{~g}, 4.86 \mathrm{mmol})$ was dissolved in $10 \mathrm{~cm}^{3}$ of toluene at room temperature and $2.77 \mathrm{~cm}^{3}$ $(2.745 \mathrm{~g}, 14.58 \mathrm{mmol})$ of diprm-H was added under stirring. The reaction mixture was stirred at $120^{\circ} \mathrm{C}$ for 3 days. $\mathrm{Al}(\mathrm{diprm})_{3}(2.651 \mathrm{~g}, 93 \%)$ was obtained as a colourless solid after removal of volatiles and drying in vacuo.

Method C: Diprm-H $\left(9.18 \mathrm{~cm}^{3}, 9.097 \mathrm{~g}, 48.33 \mathrm{mmol}\right)$ was added to $\mathrm{Al}(\mathrm{OiPr})_{3}(0.992 \mathrm{~g}, 4.86 \mathrm{mmol})$ and the mixture was stirred at $120^{\circ} \mathrm{C}$ for 3 days. Toluene $\left(2 \mathrm{~cm}^{3}\right)$ was added, resulting in dissolution of the colourless solid. After cooling to room temperature, $\mathrm{Al}(\mathrm{diprm})_{3}(2.102 \mathrm{~g}$, $74 \%$ ) was obtained as colourless crystals upon storage for few days.

${ }^{1} \mathrm{H}$ NMR $\left(\mathrm{C}_{6} \mathrm{D}_{6}, 20{ }^{\circ} \mathrm{C}\right): \delta=5.09$ (sept, $J=6.1 \mathrm{~Hz}, 6$ $\left.\mathrm{H}, \mathrm{COOCH} \mathrm{Me}_{2}\right), 4.96(\mathrm{~s}, 3 \mathrm{H}, \mathrm{COCHCO}), 1.18$ (d, $\left.J=6.1 \mathrm{~Hz}, 18 \mathrm{H}, \mathrm{COOCH}\left(\mathrm{CH}_{3}\right)_{2}\right), 1.07(\mathrm{~d}, J=6.1 \mathrm{~Hz}$, $\left.18 \mathrm{H}, \mathrm{COOCH}\left(\mathrm{CH}_{3}\right)_{2}\right) \mathrm{ppm} ;{ }^{13} \mathrm{C}\left\{{ }^{1} \mathrm{H}\right\} \mathrm{NMR}\left(\mathrm{C}_{6} \mathrm{D}_{6}, 20{ }^{\circ} \mathrm{C}\right)$ : $\delta=175.5(\mathrm{CO}), 68.0(\mathrm{COCHCO}), 67.9\left(\mathrm{COOCHMe}_{2}\right)$, $22.2\left(\mathrm{COOCH}\left(\mathrm{CH}_{3}\right)_{2}\right), 22.0\left(\mathrm{COOCH}\left(\mathrm{CH}_{3}\right)_{2}\right) \mathrm{ppm} ;{ }^{27} \mathrm{Al}$ NMR (toluene- $d_{8}, 20^{\circ} \mathrm{C}$ ): $\delta=5.3 \mathrm{ppm}$.

\section{Tris(di-tert-butylmalonato)aluminum}

(1d, $\left.\mathrm{Al}\left[\mathrm{CH}\left\{\mathrm{COOC}\left(\mathrm{CH}_{3}\right)_{3}\right\}_{2}\right]_{3}\right)$

Method $A: \mathrm{Al}(\mathrm{O} t \mathrm{Bu})_{3}(0.506 \mathrm{~g}, 2.05 \mathrm{mmol})$ was dissolved in $7 \mathrm{~cm}^{3}$ of toluene at room temperature and $1.36 \mathrm{~cm}^{3}$ $(1.314 \mathrm{~g}, 6.08 \mathrm{mmol})$ of $\mathrm{d} t \mathrm{bum}-\mathrm{H}$ was added under stirring. The reaction mixture was stirred at $80^{\circ} \mathrm{C}$ for 4 days. The solvent volume was reduced to approx. $3 \mathrm{~cm}^{3}$, and $\mathrm{Al}(\mathrm{d} t \mathrm{bum})_{3}(0.822 \mathrm{~g}, 59 \%)$ was obtained as colourless crystals after recrystallization and storage for a few days at room temperature.

Method B: $\mathrm{Al}(\mathrm{O} i \mathrm{Pr})_{3}(0.995 \mathrm{~g}, 4.87 \mathrm{mmol})$ was dissolved in $10 \mathrm{~cm}^{3}$ of toluene at room temperature and $3.27 \mathrm{~cm}^{3}$ (3.159 g, $14.61 \mathrm{mmol}$ ) of $\mathrm{d} t \mathrm{bum}-\mathrm{H}$ was added under stirring. The reaction mixture was stirred at $80{ }^{\circ} \mathrm{C}$ for 5 days. $\mathrm{Al}(\mathrm{d} t \mathrm{bum})_{3}(3.144 \mathrm{~g}, 96 \%)$ was obtained as a colourless solid after removal of volatiles and drying in vacuo. Colourless crystals suitable for single crystal XRD were obtained upon recrystallization from toluene at room temperature.

${ }^{1} \mathrm{H}$ NMR $\left(\mathrm{C}_{6} \mathrm{D}_{6}, 20{ }^{\circ} \mathrm{C}\right): \delta=4.81(\mathrm{~s}, 3 \mathrm{H}, \mathrm{COCHCO})$, $1.50\left(\mathrm{~s}, 54 \mathrm{H}, \mathrm{COOC}\left(\mathrm{CH}_{3}\right)_{3}\right) \mathrm{ppm} ;{ }^{13} \mathrm{C}\left\{{ }^{1} \mathrm{H}\right\} \mathrm{NMR}\left(\mathrm{C}_{6} \mathrm{D}_{6}\right.$, $\left.20{ }^{\circ} \mathrm{C}\right): \quad \delta=175.6 \quad(\mathrm{CO}), \quad 79.9 \quad\left(\mathrm{COOCMe}_{3}\right), \quad 69.0$ (COCHCO), $29.0\left(\mathrm{COOC}\left(\mathrm{CH}_{3}\right)_{3}\right) \mathrm{ppm}$.

Bis(di-iso-propylmalonato)bis( $\mu$-iso-propanolato)bis(iso-propanolato)dialuminum

(2c, $\left.\mathrm{Al}_{2}\left[\mathrm{OCH}\left(\mathrm{CH}_{3}\right)_{2}\right]_{4}\left[\mathrm{CH}\left\{\mathrm{COOCH}\left(\mathrm{CH}_{3}\right)_{2}\right\}_{2}\right]_{2}\right)$

$\mathrm{Al}(\mathrm{O} i \mathrm{Pr})_{3}(1.020 \mathrm{~g}, 4.99 \mathrm{mmol})$ was dissolved in $10 \mathrm{~cm}^{3}$ of toluene at room temperature and $0.95 \mathrm{~cm}^{3}(0.941 \mathrm{~g}$, $5.00 \mathrm{mmol}$ ) of diprm-H was added under stirring. The reaction mixture was stirred at $100{ }^{\circ} \mathrm{C}$ for 3 days. 
$\mathrm{Al}_{2}(\mathrm{OiPr})_{4}(\mathrm{diprm})_{2} \quad(1.577 \mathrm{~g}, 95 \%)$ was obtained as a colourless oil after removal of volatiles and drying in vacuo. ${ }^{1} \mathrm{H}$ NMR $\left(\mathrm{C}_{6} \mathrm{D}_{6}, 20{ }^{\circ} \mathrm{C}\right): \delta=5.41$ (quint, $J=6.2 \mathrm{~Hz}, 2 \mathrm{H}$, $\mathrm{COOCH} \mathrm{Me}_{2}$ ), 4.96 (quint, $J=6.2 \mathrm{~Hz}, 2 \mathrm{H}, \mathrm{COOCHMe}$ ), 4.83 (s, $2 \mathrm{H}, \mathrm{COCHCO}$ ), 4.52 (quint, $J=6.2 \mathrm{~Hz}, 2 \mathrm{H}$, $\mathrm{AlOCHMe}_{2}^{(\mathrm{t})}$ ), 4.26 (quint, $J=6.2 \mathrm{~Hz}, 2 \mathrm{H}, \mathrm{AlOCHMe}_{2}^{(\mathrm{b})}$ ), $1.49\left(\mathrm{~d}, J=6.2 \mathrm{~Hz}, 6 \mathrm{H}, \operatorname{AlOCH}\left(\mathrm{CH}_{3}\right)_{2}^{(\mathrm{b})}\right), 1.45-1.35$ $\left(\mathrm{m}, 18 \mathrm{H}, \operatorname{AlOCH}\left(\mathrm{CH}_{3}\right)_{2}^{(\mathrm{t})}+\operatorname{AlOCH}\left(\mathrm{CH}_{3}\right)_{2}^{(\mathrm{b})}\right), 1.28(\mathrm{~d}$, $\left.J=6.2 \mathrm{~Hz}, 6 \mathrm{H}, \mathrm{COOCH}\left(\mathrm{CH}_{3}\right)_{2}\right), 1.23(\mathrm{~d}, J=6.2 \mathrm{~Hz}, 6$ $\left.\mathrm{H}, \mathrm{COOCH}\left(\mathrm{CH}_{3}\right)_{2}\right), 1.10(\mathrm{~d}, J=6.2 \mathrm{~Hz}, 6 \mathrm{H}, \mathrm{COOCH}$ $\left.\left(\mathrm{CH}_{3}\right)_{2}\right), 1.05\left(\mathrm{~d}, J=6.2 \mathrm{~Hz}, 6 \mathrm{H}, \mathrm{COOCH}\left(\mathrm{CH}_{3}\right)_{2}\right) \mathrm{ppm}$; ${ }^{13} \mathrm{C}\left\{{ }^{1} \mathrm{H}\right\} \operatorname{NMR}\left(\mathrm{C}_{6} \mathrm{D}_{6}, 20{ }^{\circ} \mathrm{C}\right): \delta=175.3(\mathrm{CO}), 175.0(\mathrm{CO})$, $68.1\left(\mathrm{COOCHMe}_{2}\right), 68.0$ (COCHCO), $66.3\left(\mathrm{AlOCHMe}_{2}^{(\mathrm{b})}\right)$, $63.5\left(\mathrm{AlOCHMe}_{2}^{(\mathrm{t})}\right), 28.4\left(\mathrm{AlOCH}\left(\mathrm{CH}_{3}\right)_{2}^{(\mathrm{t})}\right), 25.5(\mathrm{AlOCH}$ $\left.\left(\mathrm{CH}_{3}\right)_{2}^{(\mathrm{b})}\right), 25.4\left(\mathrm{AlOCH}\left(\mathrm{CH}_{3}\right)_{2}^{(\mathrm{b})}\right), 22.4\left(\mathrm{COOCH}\left(\mathrm{CH}_{3}\right)_{2}\right)$, $22.3\left(\mathrm{COOCH}\left(\mathrm{CH}_{3}\right)_{2}\right), \quad 22.3 \quad\left(\mathrm{COOCH}\left(\mathrm{CH}_{3}\right)_{2}\right), \quad 22.2$ $\left(\mathrm{COOCH}\left(\mathrm{CH}_{3}\right)_{2}\right)$ ppm; ${ }^{27} \mathrm{Al} \mathrm{NMR}$ (toluene- $\left.d_{8}, 20{ }^{\circ} \mathrm{C}\right)$ : $\delta=130-20$ (tetrahedral), 5.1 (octahedral) ppm.

Bis(di-tert-butylmalonato)bis( $\mu$-iso-propanolato $)$ bis(iso-propanolato)dialuminum

(2d, $\left.\mathrm{Al}_{2}\left[\mathrm{OCH}\left(\mathrm{CH}_{3}\right)_{2}\right]_{4}\left[\mathrm{CH}\left\{\mathrm{COOC}\left(\mathrm{CH}_{3}\right)_{3}\right\}_{2}\right]_{2}\right)$

$\mathrm{Al}(\mathrm{O} i \mathrm{Pr})_{3}(1.008 \mathrm{~g}, 4.94 \mathrm{mmol})$ was dissolved in $10 \mathrm{~cm}^{3}$ of toluene at room temperature and $1.11 \mathrm{~cm}^{3}(1.072 \mathrm{~g}$, $4.96 \mathrm{mmol}$ ) of $\mathrm{d} t$ bum-H was added under stirring. The reaction mixture was stirred at $80{ }^{\circ} \mathrm{C}$ for 3 days. $\mathrm{Al}_{2}(\mathrm{O} i \mathrm{Pr})_{4}(\mathrm{~d} t \mathrm{bum})_{2} \quad(1.741 \mathrm{~g}, 98 \%)$ was obtained as a colourless crystalline solid after removal of volatiles and drying in vacuo, including crystals suitable for single crystal XRD. The ${ }^{13} \mathrm{C}$ NMR of $2 \mathbf{d}$ was recorded at $-60{ }^{\circ} \mathrm{C}$ because $\mathrm{CO}$ resonances were not detectable at $20{ }^{\circ} \mathrm{C}$. ${ }^{1} \mathrm{H} \mathrm{NMR}$ (toluene- $d_{8}, 20{ }^{\circ} \mathrm{C}$ ): $\delta=4.68(\mathrm{~s}, 2 \mathrm{H}, \mathrm{COCHCO}), 4.52$ (quint, $J=5.9 \mathrm{~Hz}, 2 \mathrm{H}, \mathrm{AlOCHMe} \mathrm{Me}_{2}^{(\mathrm{b})}$ ), 4.34 (quint, $\left.J=6.3 \mathrm{~Hz}, \quad 2 \mathrm{H}, \quad \mathrm{AlOCHMe}_{2}^{(\mathrm{t})}\right), 1.62 \quad(\mathrm{~s}, 18 \mathrm{H}$, $\left.\mathrm{COOC}\left(\mathrm{CH}_{3}\right)_{3}\right), 1.55\left(\mathrm{~d}, \mathrm{~J}=6.3 \mathrm{~Hz}, 6 \mathrm{H}, \mathrm{AlOCH}\left(\mathrm{CH}_{3}\right)_{2}^{(\mathrm{b})}\right)$, $1.51\left(\mathrm{~s}, 6 \mathrm{H}, \mathrm{COOC}\left(\mathrm{CH}_{3}\right)_{3}\right), 1.40\left(\mathrm{~s}, 12 \mathrm{H}, \mathrm{COOC}\left(\mathrm{CH}_{3}\right)_{3}\right.$, 1.40-1.32 (m, 18, $\left.\operatorname{AlOCH}\left(\mathrm{CH}_{3}\right)_{2}^{(\mathrm{t})}+\operatorname{AlOCH}\left(\mathrm{CH}_{3}\right)_{2}^{(\mathrm{b})}\right) \mathrm{ppm}$; ${ }^{13} \mathrm{C}\left\{{ }^{1} \mathrm{H}\right\}$ NMR (toluene- $d_{8},-60{ }^{\circ} \mathrm{C}$ ): $\delta=175.5$ (CO), 175.4 (CO), $80.5\left(\mathrm{COOCMe}_{3}\right), 79.9\left(\mathrm{COOCMe}_{3}\right), 69.8$ $(\mathrm{COCHCO}), 65.8\left(\mathrm{AlOCHMe}_{2}^{(\mathrm{b})}\right), 63.5\left(\mathrm{AlOCHMe}_{2}^{(\mathrm{t})}\right), 29.1$ $\left(\mathrm{COOC}\left(\mathrm{CH}_{3}\right)_{3}\right), 28.7\left(\mathrm{COOC}\left(\mathrm{CH}_{3}\right)_{3}\right), 28.3\left(\mathrm{COOC}\left(\mathrm{CH}_{3}\right)_{3}\right)$, $27.4 \quad\left(\mathrm{AlOCH}\left(\mathrm{CH}_{3}\right)_{2}^{(\mathrm{t})}\right), \quad 25.9 \quad\left(\mathrm{AlOC}\left(\mathrm{CH}_{3}\right)_{2}^{(\mathrm{b})}\right), \quad 24.5$ $\left(\mathrm{AlOCH}\left(\mathrm{CH}_{3}\right)_{2}^{(\mathrm{b})}\right) \mathrm{ppm} ;{ }^{27} \mathrm{Al} \mathrm{NMR}$ (toluene- $\left.d_{8}, 20{ }^{\circ} \mathrm{C}\right)$ : $\delta=120-40$ (tetrahedral), 4.8 (octahedral) ppm.

Tetrakis(di-iso-propylmalonato)bis( $\mu$-iso-propanolato)dialuminum

(3c, $\left.\mathrm{Al}_{2}\left[\mathrm{OCH}\left(\mathrm{CH}_{3}\right)_{2}\right]_{2}\left[\mathrm{CH}\left\{\mathrm{COOCH}\left(\mathrm{CH}_{3}\right)_{2}\right\}_{2}\right]_{4}\right)$

Colourless crystals of $\mathrm{Al}_{2}(\mathrm{O} i \mathrm{Pr})_{2}(\mathrm{~d} t \mathrm{bum})_{4}(0.468 \mathrm{~g}, 43 \%)$, suitable for single crystal XRD, were obtained from $1.557 \mathrm{~g}$ of oily $2 \mathrm{c}$ upon storage at room temperature. ${ }^{1} \mathrm{H} \mathrm{NMR}\left(\mathrm{C}_{6} \mathrm{D}_{6}\right.$, $\left.20{ }^{\circ} \mathrm{C}\right): \delta=5.28(\mathrm{t}, J=5.9 \mathrm{~Hz}, 4 \mathrm{H}, \mathrm{COOCHMe}), 5.17(\mathrm{t}$, $J=6.1 \mathrm{~Hz}, 4 \mathrm{H}, \mathrm{COOCHMe}$ ), 4.91 (s, $4 \mathrm{H}, \mathrm{COCHCO})$, 4.76 (quint, $\left.J=6.1 \mathrm{~Hz}, 2 \mathrm{H}, \mathrm{AlOC} \mathrm{Me}_{2}^{(\mathrm{b})}\right), 1.55$ (d,
$\left.J=6.1 \mathrm{~Hz}, 6 \mathrm{H}, \operatorname{AlOCH}\left(\mathrm{CH}_{3}\right)_{2}^{(\mathrm{b})}\right), 1.43(\mathrm{~d}, J=6.1 \mathrm{~Hz}$, $\left.6 \mathrm{H}, \quad \operatorname{AlOCH}\left(\mathrm{CH}_{3}\right)_{2}^{(\mathrm{b})}\right), 1.32(\mathrm{~d}, J=5.9 \mathrm{~Hz}, 12 \mathrm{H}$, $\left.\mathrm{COOCH}\left(\mathrm{CH}_{3}\right)_{2}\right), \quad 1.25-1.20\left(\mathrm{~m}, 24 \mathrm{H}, \mathrm{COOCH}\left(\mathrm{CH}_{3}\right)_{2}\right)$, $1.13\left(\mathrm{~d}, J=6.1 \mathrm{~Hz}, 12 \mathrm{H}, \mathrm{COOCH}\left(\mathrm{CH}_{3}\right)_{2}\right) \mathrm{ppm} ;{ }^{13} \mathrm{C}\left\{{ }^{1} \mathrm{H}\right\}$ NMR $\left(\mathrm{C}_{6} \mathrm{D}_{6}, 20{ }^{\circ} \mathrm{C}\right): \delta=175.1(C \mathrm{O}), 174.5(C \mathrm{O}), 68.4$ $(\mathrm{COCHCO}), 67.2\left(\mathrm{COOCHMe}_{2}\right), 67.1 \quad\left(\mathrm{COOCHMe}_{2}\right)$, $64.4\left(\mathrm{AlOCHMe}{ }_{2}^{(\mathrm{b})}\right), 25.4\left(\mathrm{AlOCH}\left(\mathrm{CH}_{3}\right)_{2}^{(\mathrm{b})}\right), 24.0(\mathrm{AlOCH}$ $\left.\left(\mathrm{CH}_{3}\right)_{2}^{(\mathrm{b})}\right), 23.2\left(\mathrm{COOCH}\left(\mathrm{CH}_{3}\right)_{2}\right), 22.6\left(\mathrm{COOCH}\left(\mathrm{CH}_{3}\right)_{2}\right)$, $22.5\left(\mathrm{COOCH}\left(\mathrm{CH}_{3}\right)_{2}\right) \mathrm{ppm} ;{ }^{27} \mathrm{Al} \mathrm{NMR}$ (toluene- $\left.d_{8}, 20{ }^{\circ} \mathrm{C}\right)$ : $\delta=3.5$ (octahedral) ppm.

\section{Pentakis(diethylmalonato)tris( $\mu$-ethanolato)-} ( $\mu$-hydroxo)trialuminium

(4, $\left.\mathrm{Al}_{3}(\mathrm{OH})\left(\mathrm{OCH}_{2} \mathrm{CH}_{3}\right)_{3}\left[\mathrm{CH}\left(\mathrm{COOCH}_{2} \mathrm{CH}_{3}\right)_{2}\right]_{5}\right)$

Toluene $\left(10 \mathrm{~cm}^{3}\right)$ and subsequently $2.80 \mathrm{~cm}^{3}$ of detm-H $(2.954 \mathrm{~g}, 18.44 \mathrm{mmol})$ were added to $\mathrm{Al}(\mathrm{OEt})_{3}(1.007 \mathrm{~g}$, $6.21 \mathrm{mmol})$ at room temperature. The mixture was stirred at $90{ }^{\circ} \mathrm{C}$ for 4 days, whereupon it cleared. Removal of the volatiles in vacuo gave a slightly greenish oil which crystallized upon storage at room temperature for several days to give $\mathrm{Al}_{3}(\mathrm{OH})(\mathrm{OEt})_{3}(\mathrm{~d} i \mathrm{prm})_{5}(1.874 \mathrm{~g}, 88 \%)$ as colourless crystals suitable for single crystal XRD. ${ }^{1} \mathrm{H}$ NMR $\left(\mathrm{C}_{6} \mathrm{D}_{6}, 20{ }^{\circ} \mathrm{C}\right): \delta=4.91(\mathrm{~s}, 5 \mathrm{H}, \mathrm{COCHCO}), 4.60-4.43(\mathrm{~m}$, $\left.6 \mathrm{H}, \mathrm{AlOCH}{ }_{2} \mathrm{Me}\right), 4.12-3.92\left(\mathrm{~m}, 22 \mathrm{H}, \mathrm{COOCH}_{2} \mathrm{Me}+\right.$ AlOCH$\left.H_{2} \mathrm{Me}\right), 3.84-3.72\left(\mathrm{~m}, 4 \mathrm{H}, \mathrm{AlOCH}_{2} \mathrm{Me}\right), 1.33(\mathrm{t}$, $\left.J=6.6 \mathrm{~Hz}, 9 \mathrm{H}, \mathrm{AlOCH}_{2} \mathrm{CH}_{3}\right), 1.14(\mathrm{t}, J=6.9 \mathrm{~Hz}, 15 \mathrm{H}$, $\left.\mathrm{COOCH}_{2} \mathrm{CH}_{3}\right), 0.99\left(\mathrm{t}, \mathrm{J}=6.9 \mathrm{~Hz}, 15 \mathrm{H}, \mathrm{COOCH}_{2} \mathrm{CH}_{3}\right)$ ppm; ${ }^{13} \mathrm{C}\left\{{ }^{1} \mathrm{H}\right\}$ NMR $\left(\mathrm{C}_{6} \mathrm{D}_{6}, 20{ }^{\circ} \mathrm{C}\right): \delta=175.4(\mathrm{CO}), 66.4$ (COCHCO), $60.1\left(\mathrm{COOCH}_{2} \mathrm{Me}\right), 60.0\left(\mathrm{COOCH}_{2} \mathrm{Me}\right), 56.6$ $\left(\mathrm{AlOCH} \mathrm{H}_{2} \mathrm{Me}\right), 18.4\left(\mathrm{AlOCH}_{2} \mathrm{CH}_{3}\right), 14.6\left(\mathrm{COOCH}_{2} \mathrm{CH}_{3}\right)$, $14.4\left(\mathrm{COOCH}_{2} \mathrm{CH}_{3}\right) \mathrm{ppm} ;{ }^{27} \mathrm{Al} \mathrm{NMR}$ (toluene- $\left.d_{8}, 20{ }^{\circ} \mathrm{C}\right)$ : $\delta=5.9$ ppm.

\section{$X$-ray structure analyses}

Crystals of 1a, $\mathbf{1 d} \cdot 0.5$ toluene, $\mathbf{2 d}, \mathbf{3 c}$, and $\mathbf{4}$ suitable for single crystal XRD were mounted on a Bruker AXS KAPPA diffractometer fitted with an APEX II CCD area detector, using graphite-monochromated $\mathrm{Mo}-\mathrm{K}_{\alpha}$ radiation $(\lambda=$ $71.073 \mathrm{pm}$ ). Data collection at $100 \mathrm{~K}$ covered a hemisphere of the reciprocal space by recording three sets of exposures, each of them exhibiting a different $\Phi$ angle. Each exposure covered $0.3^{\circ}$ in $\omega$ (Table 1 ). The data were corrected for polarization and Lorentz effects, and an empirical absorption correction (SADABS) was applied. The cell dimensions were refined with all unique reflections. The structures were solved with direct methods (SHELXS97) and refinement to convergence was carried out with the full-matrix least squares method based on F2 (SHELXL97) with anisotropic structure parameters for all non-hydrogen atoms. The hydrogen atoms were placed on calculated positions and refined riding on their parent atoms. Selected bond lengths and angles are compared in Table 2. 
Table 1 Crystallographic and structural parameters of 1a, 1d, 2d, 3c and 4

\begin{tabular}{|c|c|c|c|c|c|}
\hline & $1 \mathbf{a}$ & 1d 0.5 toluene & $2 d$ & $3 c$ & 4 \\
\hline Empirical formula & $\mathrm{C}_{15} \mathrm{H}_{21} \mathrm{AlO}_{12}$ & $\mathrm{C}_{73} \mathrm{H}_{122} \mathrm{Al}_{2} \mathrm{O}_{24}$ & $\mathrm{C}_{34} \mathrm{H}_{66} \mathrm{Al}_{2} \mathrm{O}_{12}$ & $\mathrm{C}_{42} \mathrm{H}_{74} \mathrm{Al}_{2} \mathrm{O}_{18}$ & $\mathrm{C}_{41} \mathrm{H}_{71} \mathrm{Al}_{3} \mathrm{O}_{24}$ \\
\hline Formula weight & 420.3 & $1,437.67$ & 720.83 & 920.97 & $1,028.92$ \\
\hline Crystal system & Monoclinic & Triclinic & Triclinic & Orthorhombic & Triclinic \\
\hline Space group & $C 2 / \mathrm{c}$ & $P-1$ & $P-1$ & $P 2{ }_{1} 2_{1} 2_{1}$ & $P-1$ \\
\hline \multicolumn{6}{|l|}{ Unit cell dimensions } \\
\hline$a(\mathrm{pm})$ & $1,557.41(18)$ & $1,011.89(5)$ & $1,270.21(9)$ & $1233.3(2)$ & $1,237.19(14)$ \\
\hline$b(\mathrm{pm})$ & $1,634.10(19)$ & $1,118.28(5)$ & $1,949.16(14)$ & 2118.3(4) & $1,479.98(17)$ \\
\hline$c(\mathrm{pm})$ & 766.74(9) & $1,901.72(8)$ & $1,980.94(14)$ & $3,965.2(8)$ & $1,500.80(17)$ \\
\hline$\alpha\left({ }^{\circ}\right)$ & & $74.787(1)$ & $64.924(1)$ & 90 & $74.305(2)$ \\
\hline$\beta\left(^{\circ}\right)$ & $103.132(2)$ & $85.206(1)$ & $74.446(1)$ & 90 & $81.936(2)$ \\
\hline$\gamma\left({ }^{\circ}\right)$ & & $81.489(1)$ & $84.206(1)$ & 90 & $77.301(2)$ \\
\hline Volume $\left(\mathrm{pm}^{3}\right) \times 10^{6}$ & $1,900.3(4)$ & $2,051.41(16)$ & $4,279.1(5)$ & $10,359(3)$ & $2,571.2(5)$ \\
\hline$Z$ & 4 & 1 & 4 & 8 & 2 \\
\hline Calcd. density $\left(\mathrm{g} / \mathrm{cm}^{3}\right)$ & 1.469 & 1.164 & 1.119 & 1.181 & 1.329 \\
\hline Absorption coeff. $\mu\left(\mathrm{mm}^{-1}\right)$ & 0.169 & 0.105 & 0.120 & 0.121 & 0.154 \\
\hline Crystal size (mm) & $0.56 \times 0.23 \times 0.17$ & $0.57 \times 0.48 \times 0.37$ & $0.53 \times 0.37 \times 0.16$ & $0.60 \times 0.30 \times 0.10$ & $0.57 \times 0.47 \times 0.26$ \\
\hline$\theta$ range $\left(^{\circ}\right)$ & $3.02-27.49$ & $2.60-25.00$ & $1.78-25.00$ & $1.73-25.00$ & $2.44-25.00$ \\
\hline Reflections coll./unique & $6,283 / 2,170$ & $11,229 / 7,168$ & $38,427 / 15,018$ & $54,453 / 9,938$ & $26,695 / 9,065$ \\
\hline Data/parameters & $2,170 / 131$ & $7,168 / 497$ & $15,018 / 965$ & $9,938 / 1,175$ & $9,065 / 709$ \\
\hline GOF on $F^{2}$ & 1.138 & 1.023 & 0.957 & 1.094 & 1.073 \\
\hline$R[I>2 \sigma(I)]$ & 0.0382 & 0.0365 & 0.0536 & 0.0749 & 0.0342 \\
\hline $\mathrm{w} R 2$ & 0.0951 & 0.0954 & 0.1362 & 0.1825 & 0.0903 \\
\hline Largest diff. peak/hole $\left(\mathrm{e} \AA^{-3}\right)$ & $0.292 /-0.296$ & $0.265 /-0.268$ & $0.582 /-0.485$ & $0.744 /-0.403$ & $0.590 /-0.544$ \\
\hline
\end{tabular}

Table 2 Comparison of selected bond distances (pm) and angles $\left({ }^{\circ}\right)$ of 1a, 1d, 2d, 3c and 4

\begin{tabular}{llllll}
\hline & 1a & 1d & 2d & 3c & 4 \\
\hline Al-O ${ }^{\text {malonate }}$ & $186.9(1)-189.3(1)$ & $186.9(1)-188.5(1)$ & $188.3(2)-188.6(2)$ & $190.1(4)-192.5(4)$ & $189.2(1)-194.8(1)$ \\
Al-O & & & $179.8(2), 179.1(2)$ & $186.8(4), 188.7(4)$ & $184.4(1)-184.9(1)$ \\
& & & $190.3(2), 190.2(2)$ & $187.7(4), 186.7(4)$ & $187.6(1)-189.6(1)$ \\
$\mathrm{O}^{\text {malonate }}-\mathrm{Al}-\mathrm{O}^{\text {malonate }}$ & $90.53(5)$ & $90.39(4)-91.36(4)$ & $90.29(7), 90.39(7)$ & $88.9(2)-89.3(2)$ & $88.3(5)-89.3(5)$ \\
$\mathrm{O}^{\text {alkoxo (b) }}-\mathrm{Al}-\mathrm{O}^{\text {alkoxo (b) }}$ & & & $82.17(7), 76.61(7)$ & $77.6(2), 77.9(2)$ & $75.28(5)-78.23(5)^{\mathrm{a}}$ \\
$\mathrm{Al}-\mathrm{O}^{\text {alkoxo (b) }}-\mathrm{Al}$ & & & $100.46(7), 100.75(7)$ & $102.23(19), 101.9(2)$ & $101.09(3)-103.13(5)^{\mathrm{a}}$ \\
\hline
\end{tabular}

Superscript (b) indicates bridging binding of $\mathrm{O}^{\text {alkoxo }}$

a $\mathrm{O}^{\text {hydroxo (b) }}$ instead of one $\mathrm{O}^{\text {alkoxo (b) }}$

In the crystal structure of $\mathbf{2 d}$ one $\mathrm{O} i \mathrm{Pr}$, in $\mathbf{3 c}$ two $\mathrm{O} i \mathrm{Pr}$, and in $\mathbf{4}$ two malonate and two aluminium-bound $\mathrm{OEt}$ groups are disordered.

CCDC-742538 (for 1a), 742539 (for 1d), 742540 (for 2c), 742541 (for 3c), and 742542 (for 4) contain the supplementary crystallographic data for this paper. These data can be obtained free of charge from The Cambridge Crystallographic Data Centre via http://www.ccdc.cam. ac.uk/data_request/cif.

Acknowledgments This work was supported by the Fonds zur Förderung der wissenschaftlichen Forschung (FWF), Austria (Project
P20750). The authors thank R. Hellein and M. Schwabl for their supporting experimental work.

Open Access This article is distributed under the terms of the Creative Commons Attribution Noncommercial License which permits any noncommercial use, distribution, and reproduction in any medium, provided the original author(s) and source are credited.

\section{References}

1. Livage J, Henry M, Sanchez C (1988) Prog Solid State Chem $18: 259$ 
2. Schubert U (2005) J Mater Chem 15:3701

3. Shiner VJ Jr, Whittaker D, Vernandez VP (1963) J Am Chem Soc 85:2318

4. Turova NY, Kozuniv VA, Yanovskii AI, Bokii NG, Struchkov YT, Tarnopol'skii BL (1979) J Inorg Nucl Chem 41:5

5. Abraham A, Prins R, van Bokhoven JA, Van Eck ERH, Kentgens APM (2006) J Phys Chem B 110:6553

6. Cayton RH, Chisholm MH, Davidson ER, DiStasi VF, Du P, Huffman JC (1991) Inorg Chem 30:1020

7. Kriz O, Casensky B, Lycka A, Fusek J, Hermanek S (1984) J Magn Reson 60:375

8. Wengrovius JH, Garbauskas MF, Williams EA, Goint RC, Donahue PE, Smith JF (1986) J Am Chem Soc 108:982

9. Garbauskas MF, Wengrovius JH, Going RC, Kasper JS (1984) Acta Crystallogr C 40:1536

10. Garbauskas MF, Wengrovius JH (1987) Acta Crystallogr C 43:2441

11. Schubert U (2004) In: McCleverty JA, Meyer TJ (eds) Comprehensive coordination chemistry II. Elsevier, Amsterdam

12. Lichtenberger R, Puchberger M, Baumann SO, Schubert U (2009) J Sol Gel Sci Technol 50:130

13. Milanov A, Bhakta R, Thomas R, Ehrhart P, Winter M, Waser R, Devi A (2006) J Mater Chem 16:437

14. Baunemann A, Hellwig M, Varade A, Bhakta RK, Winter M, Shivashankar SA, Fischer RA, Devi A (2006) Dalton Trans 3485

15. Gueta-Neyroud T, Tumanskii B, Botoshansky M, Eisen MS (2007) J Organomet Chem 692:927
16. Paerssinen A, Elo P, Klinga M, Leskelae M, Repo T (2006) Inorg Chem Commun 9:859

17. Sobota P, Szafert S, Glowiak T (1996) J Organomet Chem 526:329

18. Hellwig M, Milanov A, Barecca D, Deborde J-L, Thomas R, Winter M, Kunze U, Fischer RA, Devi A (2007) Chem Mater 19:6077

19. Thomas R, Milanov A, Bhakta R, Patil U, Winter M, Ehrhart P, Waser R, Devi A (2006) Chem Vap Depos 12:295

20. Schubert U (2003) J Sol Gel Sci Technol 26:47

21. Ivanovici S, Puchberger M, Fric H, Kickelbick G (2007) Monatsh Chem 138:529

22. Ivanovici S, Peterlik H, Feldgitscher C, Puchberger M, Kickelbick G (2008) Macromolecules 41:1131

23. Hubert-Pfalzgraf LG, Pajot N, Papiernik R, Parraud S (1996) Mater Res Soc Symp Proc 435:137

24. Cauro-Gamet LC, Hubert-Pfalzgraf LG, Lecocq S (2004) Z Anorg Allg Chem 630:2071

25. Kleinschmidt DC, Shiner VJ Jr, Whittaker D (1973) J Org Chem 38:3334

26. Dharmaprakash MS, Thamotharan S, Neelgund GM, Shivashankar SA (2006) Acta Crystallogr E 62:m434

27. Diaz-Acosta I, Baker J, Cordes W, Pulay P (2001) J Phys Chem A $105: 238$

28. Shulman GP, Trusty M, Vickers JH (1963) J Org Chem 28:907

29. Armarego WLF, Perrin DD (1997) Purification of laboratory chemicals, 4th edn. Elsevier, Amsterdam 